\title{
Study on Nurse Image perceived by High School Students and Intention to Consider Nursing when Selecting a Career
}

\author{
Mi-Kyung Jeon ${ }^{1 *}$, So-Ja Jeon ${ }^{1}$ and Yang-Sin Kim² \\ 'Department of Nursing, Munkyung College, Republic of Korea; mk4311@lycos.co.kr \\ ${ }^{2}$ Department of Nursing, Chungbuk Health and Science University, Republic of Korea
}

\begin{abstract}
To lay the foundation of strategy development for improving the nurse image of the future by grasping the nurse image and to provide the basic data for promoting the application of excellent students to nursing by grasping the awareness which can affect their careers, this study was conducted for the high school students who were in the stage of a career choice. This study was conducted from June 20, 2014 to July 31, 2014 and the data from the 320 male and female students of 4 high schools in $\mathrm{M}$ and $\mathrm{S}$ regions was used for analysis. The collected data was analyzed by frequency, percentage, t-test, ANOVA, and Pearson's correlation coefficients according to the study purpose with SPSS Window 21.0 Program. The results of the study are as follows: First, in a correlation between nurse image perceived by high school students and the characteristics of a career choice, it was indicated that the nurse image perceived by high school students had a correlation with the subjects to consult with for a career choice $(\mathrm{r}=-.124, \mathrm{p}=.027)$, whether they have intention to consider nursing $(\mathrm{r}=-.133$, $\mathrm{p}=.017)$, why they consider nursing $(\mathrm{r}=-.122, \mathrm{p}=.029)$, and why they don't consider nursing $(\mathrm{r}=114, \mathrm{p}=.041)$.Second, in the correlation of image and the characteristics of a career, the occupational image had a correlation with business image $(\mathrm{r}=.642, \mathrm{p}=.000)$, the social image did with business image $(\mathrm{r}=.530, \mathrm{p}=.000)$ and the occupational image $(\mathrm{r}=.671$, $\mathrm{p}=.000)$, and the individual image did with business image $(\mathrm{r}=.831, \mathrm{p}=.000)$, the occupational image $(\mathrm{r}=.609$, $\mathrm{p}=.000)$, and the social image $(\mathrm{r}=.581, \mathrm{p}=.000)$. The subjects to consult with for a career choice did with business image $(\mathrm{r}=-.132, \mathrm{p}=.018)$ and individual image $(\mathrm{r}=-.137, \mathrm{p}=.014)$, whether they have intention to consider nursing did with the occupational image $(\mathrm{r}=-.205, \mathrm{p}=.000)$ and the social image $(\mathrm{r}=-.237, \mathrm{p}=.000)$, why they consider nursing did with the occupational image $(r=-.195, p=.000)$, the social image $(r=-.221, p=.000)$ and whether they have intention to consider nursing $(r=.969, \mathrm{p}=.000)$, and why they don't consider nursing did with the occupational image $(\mathrm{r}=.143, \mathrm{p}=.010)$, the social image $(r=.144, p=.010)$ and whether they have intention to consider nursing $(r=-.666, p=.000)$.
\end{abstract}

Keywords: Career Choice, High School Students, Perceived Nurse Image, Subjects of Consultation

\section{Introduction}

\subsection{Need for the Study}

Examining the perception of the public on a nurse, in the past, he or she was perceived as a person who works as an assistant to a doctor and who has a negative predisposition $^{1}$, and the classical image of a nurse is that he or she is like a white-robed angel who is feminine and passive and who requires sacrifice and spirit of service ${ }^{2}$. However, today, there is perception that he or she is a professional who does a worthwhile and rewarding job and it is true that he or she has been recognized a person who is dependent and lacks a positive motivation so far ${ }^{3}$. It wasn't until recently that the role of a nurse has come to take charge of the mental, psychological and spiritual nursing as well as a direct, physical nursing, and the subjects of the nursing have become expanded to the individuals, families and communities. Also, as the demand of medical consumers gets higher with the improvement in a medical level, the role of a nurse is getting subdivided. At this time, it is

${ }^{*}$ Author for correspondence 
ineffective to classify the role of males and females, and it is hard to perform a high level of nursing which is getting specialized and to meet the improved demand of the subjects only with the characteristics of feminity.

Therefore, when the advantages of masculinity and feminity get mixed harmoniously, a significant synergy effect will be displayed in the development of nursing where professionalism is emphasized. Nursing science has achieved a steady internal, external growth as a result of concentrating on the status as a profession along with an academic development. And it is recognized that a nurse is a professional who plays a pivotal role in curing patients in the health care system recently ${ }^{4}$. Nurses in a realm of a profession help the health and recovery of patients and improve the self care ability of the subjects by providing an independent nursing with a deep affection, respect and love to patients. Also, they are performing a role as a professional who plays a central role in curing a patient, and the supporter, adjustor and educator of the subjects. Further, through the health consultation in a community, industrial sites, and a school, they have an important place in helping health problems ${ }^{5}$. On these days, the urgency of career education is keenly being felt in a family, a school and all levels of society. The reason is that the high school students who want to go to a college don't decide to apply to which department of a college with confidence as they lose sense of direction during every exam season ${ }^{6}$. Also, whether getting a job is guaranteed or not in the future works as the most important factor in selecting a career. Today, it is indicated that many colleges have difficulty in recruiting fresh men due to the reduction of college school age population. The number of the graduates of a high school (including academic, vocational high schools) in 2008 was 581,916, while the entrance quota of a college (except for Korean National Open University (KNOU), technology colleges, corporate universities) was 642,526 ones (Ministry of Education and Science Technology (MEST), which showed a lack of 60,610 students. It seems that this insufficient recruit rate of a college will be intensified year on year due to the reduction of population, and the reduction of college school age population may lead to the problem of keeping or discarding a college itself. Therefore, every college is applying various marketing strategies for attracting excellent students. Although a department of nursing science is showing a high rate of application compared with other departments in this intense competition, however, it is desperate to do a various, positive promotion to induce excellent students to apply to a department of nursing science. Also, this strategy seems to contribute greatly to the development of a nursing profession ultimately ${ }^{7}$. Therefore, by grasping the recognition and image of nurses from the high school students who are in the stage of a career choice in a rapidly changing medical, societal environment, this study is aimed to lay the foundation of strategy development for improving the image of nurses, and by grasping the high school students who will select nursing and the awareness which can affect their career, it is aimed to provide a basic data for promoting the application of excellent high school students to nursing.

\subsection{Objectives of the Study}

Specific objectives of the study are as follows:

1. Grasp the general characteristics of high school students.

2. Grasp the degree of the nurse image perceived by high school students.

3. Grasp the relationship between the nurse image perceived by high school students and the characteristics of a career choice.

4. Grasp the characteristics of a career choice of high school students.

5. Grasp the relationship between the image of nurses by the sub-regions perceived by high school students and the characteristics of a career choice.

\section{Research Methods}

\subsection{Research Design}

This study is a descriptive survey research which was conducted to grasp the image and recognition of a nurse perceived by high school students in $\mathrm{M}$, and $\mathrm{S}$ regions and whether they consider nursing or not when selecting a career.

\subsection{Subjects and Ethical Consideration}

As the subjects of the study, the 400 male, female students of 4 high schools in $\mathrm{M}, \mathrm{S}$ regions were conveniently sampled and data was collected anonymously. Explaining that what replied to the survey would not be used for any other use besides the objects of this study, that they could refuse to participate in the study and stop halfway through at any time as they voluntarily participated in it, and that they would not be disadvantaged in any way, the signature was collected from participants on a consent form. 


\subsection{Instruments}

The tools used in this study consisted of the general characteristics of the subjects (5 questions), the characteristics related with nursing recognition (5 questions), nurse image (50 questions), and a career choice (5 questions).

\subsubsection{General Characteristics of Subjects}

The general characteristics consisted of 5 questions in total, that is, gender, course, religion, and school record. The characteristics related with nursing consisted of 5 questions, that is, whether they have nursing practitioners among their family or relatives or not, whether they have ever been introduced or explained about nursing or not, details of how their recognition on nursing have been largely affected, and whether they or their family have an experience of hospitalization or not.

\subsubsection{Tools for Nurse Image}

Based on Lee's ${ }^{8}$ study, each region on the nurse image was classified into business image (8 questions), social image ( 7 ones), occupational image (13 ones), and individual image ( 21 ones), which consisted of 50 questions in total. The reliability of the nurse image in this study was Chronbach's $\alpha=.93$. By sub-regions, they were as follows, business image (Chronbach's $\alpha=.83$ ), social image (Chronbach's $\alpha=.64$ ), occupational image (Chronbach's $\alpha=.70$ ), and individual image (Chronbach's $\alpha=.87$ ).

\subsubsection{Tools for a Career Choice}

Based on the study of Moon 7 , this tool consisted of 5 questions in total, that is, the major subjects of career consultation, whether they consider nursing or not, why they consider nursing, why they don't consider nursing, and whether they have intention to participate in when the information for nursing is provided.

\subsection{Data Collection}

In this study, data was collected with a questionnaire method, one of the self-reported methods, and data was collected from June 20, 2014 to July 31, 2014. A surveyor visited the high schools in $\mathrm{M}, \mathrm{S}$ regions in person, explained the purpose of the study, distributed questionnaires and collected data from the subjects who agreed to the survey. The 400 questionnaires in total were distributed, 350 questionnaires were collected, and 320 ones (91.4\%) except for 30 ones which responded to the questions indistinctly were used for the data of this study.

\subsection{Data Analysis}

The data collected in this study was statistically processed using SPSS Window 21.0 program. The general characteristics of subjects, the degree of the nurse image perceived, the characteristics of the career choice of high school students were analyzed by frequency and percentage, and average and standard deviation, the comparison of difference in the degree of nurse image perceived according to the general characteristics of high school students was done with t-test and ANOVA, post-hoc was done with Scheffe's test, the relationship between the nurse image perceived by high school students and the characteristics of a career choice was done with Pearson's correlation Coefficients.

\section{Research Results}

\subsection{General Characteristics of High School Students}

As for the general characteristics of subjects, 'by grades', there were 243 students (75.9\%) in 3rd grade and 77 ones (24.1\%) in 2nd grade, 'by gender', there were 184 male ones $(57.5 \%)$ and 136 female ones (42.5\%), 'by course', there were 161 ones (50.3\%) in liberal arts and 159ones $(49.7 \%)$ in natural sciences, 'by religion', 184 students (57.5\%) answered 'no religion', followed by 'Christianity' 57(17.8\%), 'Buddhism' 42(13.1\%), and 'Catholic'21(6.6\%). As for school record, the results were as follows, 'average' 193(60.3\%), 'good' 89(27.8\%), and 'bad' 38(11.9\%), and as for 'nursing practitioners around', the results were in order of 'no' 236(73.8\%), and 'yes' $84(26.3 \%)$. In 'the experience of information provision for nursing', 225(70.3\%) answered 'no' and 95(29.7\%) answered 'yes'. In 'tendency of recognition of nursing', it was in order of 'books or mass media' 167(52.2\%), 'experience of hospitalization' 64(20.0\%), and 'teachers or acquaintances' 49(15.3\%). In 'hospitalization period', it was revealed that 84 ones (26.3\%) were hospitalized 'within 7 days', and 68(21.3\%) were 'over 7 days', and in 'experience of family hospitalization', 247(77.2\%) answered 'yes', and 73(22.8\%) answered 'no' (Table 1).

\subsection{Degree of Nurse Image Perceived by High School Students}

In the degree of nurse image perceived by high school students, the mean of the whole image was 3.39 points, 
Table 1. General characteristicsof subjects

\begin{tabular}{|c|c|c|c|}
\hline \multirow[t]{2}{*}{ Characteristics } & \multicolumn{3}{|c|}{$\begin{array}{l}\text { General Characteristics of subjects } \\
\qquad(\mathrm{N}=320)\end{array}$} \\
\hline & Division & Number (\%) & Mean \\
\hline \multirow{2}{*}{ Grade } & $2 \mathrm{nd}$ & $77(24.1 \%)$ & \\
\hline & $3 \mathrm{rd}$ & $243(75.9 \%)$ & \\
\hline \multirow{2}{*}{ Gender } & Male & $184(57.5 \%)$ & \\
\hline & Female & $136(42.5 \%)$ & \\
\hline \multirow{2}{*}{ Course } & Liberal Arts & $161(50.3 \%)$ & \\
\hline & Natural Sciences & $159(49.7 \%)$ & \\
\hline \multirow{5}{*}{ Religion } & Christianity & $57(17.8 \%)$ & \\
\hline & Catholic & $21(6.6 \%)$ & \\
\hline & Buddhism & $42(13.1 \%)$ & \\
\hline & No Religion & $184(57.5 \%)$ & \\
\hline & Others & $16(5.0 \%)$ & \\
\hline \multirow{3}{*}{ School Record } & Good & $89(27.8 \%)$ & \\
\hline & Average & $193(60.3 \%)$ & \\
\hline & Bad & $38(11.9 \%)$ & \\
\hline \multirow{2}{*}{$\begin{array}{c}\text { Nursing } \\
\text { Practitioner } \\
\text { Around }\end{array}$} & Yes & $84(26.3 \%)$ & \\
\hline & No & $236(73.8 \%)$ & \\
\hline \multirow{2}{*}{$\begin{array}{l}\text { Experience of } \\
\text { Information } \\
\text { Provision of } \\
\text { Nursing }\end{array}$} & Yes & $95(29.7 \%)$ & \\
\hline & No & $225(70.3 \%)$ & \\
\hline \multirow{4}{*}{$\begin{array}{l}\text { Effect on } \\
\text { Recognition of } \\
\text { Nursing }\end{array}$} & $\begin{array}{l}\text { Books or Mass } \\
\text { Media }\end{array}$ & $167(52.2 \%)$ & \\
\hline & $\begin{array}{l}\text { Teachers or } \\
\text { Acquaintances } \\
\text { Around }\end{array}$ & $49(15.3 \%)$ & \\
\hline & $\begin{array}{l}\text { Experience of } \\
\text { Hospitalization }\end{array}$ & $64(20.0 \%)$ & \\
\hline & Others & $40(12.5 \%)$ & \\
\hline \multirow{2}{*}{$\begin{array}{l}\text { Experience of } \\
\text { Hospitalization }\end{array}$} & Yes & $150(46.9 \%)$ & \\
\hline & No & $170(53.1 \%)$ & \\
\hline \multirow{2}{*}{$\begin{array}{l}\text { Hospitalization } \\
\text { Period }\end{array}$} & Within 7 days & $84(26.3 \%)$ & \\
\hline & Over 7 days & $68(21.3 \%)$ & \\
\hline \multirow{2}{*}{$\begin{array}{c}\text { Experience } \\
\text { of Family } \\
\text { Hospitalization }\end{array}$} & Yes & $247(77.2 \%)$ & \\
\hline & No & $73(22.8 \%)$ & \\
\hline
\end{tabular}

individual image 3.53 points, business image 3.49 points, social image 3.26 points and occupational image 3.17 points (Table 2 ).
Table 2. Degree of image perceived by high school students

\begin{tabular}{|c|c|c|c|c|}
\hline \multirow{2}{*}{} & \multicolumn{4}{|c|}{$\begin{array}{c}\text { Degree of Nurse Image Perceived By } \\
\text { High School Students } \\
\mathrm{N}=320\end{array}$} \\
\hline Variables & Division & Mean(SD) & Range & $\begin{array}{c}\text { Observed } \\
\text { rage }\end{array}$ \\
\hline Image & & 3.39 & $1-5$ & $2.10-4.60$ \\
\hline & $\begin{array}{c}\text { Business } \\
\text { Image }\end{array}$ & 3.49 & $1-5$ & $2.13-4.93$ \\
\cline { 2 - 5 } & $\begin{array}{c}\text { Occupational } \\
\text { Image }\end{array}$ & 3.17 & $1-5$ & $1.69-4.38$ \\
\cline { 2 - 5 } & Social Image & 3.26 & $1-5$ & $1.86-4.71$ \\
\cline { 2 - 5 } & $\begin{array}{c}\text { Individual } \\
\text { Image }\end{array}$ & 3.53 & $1-5$ & $2.07-4.93$ \\
\hline
\end{tabular}

\subsection{Characteristics of Career Choice of High School Students}

In the characteristics of the career choice of high school students, the subjects to consult with for a career were parents 151(47.2\%), friends or seniors $81(25.3 \%)$, and teachers $46(14.4 \%)$. For 'whether they have intention to consider nursing or not', 265 students (82.8\%) answered 'no' and 55(17.2\%) did 'yes' (17.2\%). Among those who answered 'yes' on 'why they consider nursing', 12 students answered 'service to mankind' (3.8\%), 11 did 'stable job' (3.4\%). For 'whether they will participate in information provision for nursing or not', there were 48 students (15.1\%) in 'yes' (15.1\%) and 7 ones $(2.2 \%)$ in 'no'. However, for 'why they don't consider nursing', there were $111(34.7 \%)$ in 'not right for them' and 48 in 'grade' (15.0\%), and for 'whether they will participate in information provision for nursing or not', there were 187(58.4\%) in 'no' and 77(24.1\%) in 'yes' (Table 3).

\subsection{Relationship between Nurse Image Perceived by High School Students and Characteristics of a Career Choice}

Review of a correlation between the nurse image perceived by high school students and the characteristics of career choice revealed that the nurse image perceived by high school students had a correlation with the subjects to consult with for a career choice $(\mathrm{r}=-.124, \mathrm{p}=.027)$, whether they have intention to consider nursing or not $(\mathrm{r}=-.133$, $\mathrm{p}=.017)$, why they consider nursing $(\mathrm{r}=-.122, \mathrm{p}=.029)$, and why they do not $(\mathrm{r}=114, \mathrm{p}=.041)$. 
Table 3. Characteristics of choice of high school students

\begin{tabular}{|c|c|c|c|}
\hline \multirow[t]{2}{*}{ Characteristics } & \multicolumn{3}{|c|}{$\begin{array}{l}\text { Characteristics of Career Choice of High } \\
\qquad \begin{array}{c}\text { School Students } \\
\mathrm{N}=320\end{array}\end{array}$} \\
\hline & Division & Number (\%) & Mean \\
\hline \multirow{5}{*}{$\begin{array}{c}\text { Subjects } \\
\text { of Career } \\
\text { Consultation }\end{array}$} & Parents & $151(47.2 \%)$ & \\
\hline & Teacher & $46(14.4 \%)$ & \\
\hline & Brothers \& Sisters & $26(8.1 \%)$ & \\
\hline & Friends or Seniors & $81(25.3 \%)$ & \\
\hline & Others & $16(5.0 \%)$ & \\
\hline \multirow{2}{*}{$\begin{array}{l}\text { Whether they } \\
\text { have intention } \\
\text { to consider } \\
\text { nursing or not }\end{array}$} & Yes & $55(17.2 \%)$ & \\
\hline & No & $265(82.8 \%)$ & \\
\hline \multirow{11}{*}{$\begin{array}{l}\text { Reason to } \\
\text { Consider } \\
\text { Nursing }\end{array}$} & Right for It & $3(0.9 \%)$ & \\
\hline & Stable Job & $11(3.4 \%)$ & \\
\hline & Easy to Be Employed & $6(1.9 \%)$ & \\
\hline & $\begin{array}{c}\text { Family } \\
\text { Recommendation }\end{array}$ & $8(2.5 \%)$ & \\
\hline & Service to Mankind & $12(3.8 \%)$ & \\
\hline & Use for Daily Life & $6(1.9 \%)$ & \\
\hline & Fit for School Report & $1(0.3 \%)$ & \\
\hline & Promising Job & $4(1.3 \%)$ & \\
\hline & $\begin{array}{c}\text { Opportunity for } \\
\text { Overseas Employment }\end{array}$ & $3(0.9 \%)$ & \\
\hline & Others & $1(0.3 \%)$ & \\
\hline & None & $265(82.8 \%)$ & \\
\hline \multirow{3}{*}{$\begin{array}{l}\text { Participation } \\
\text { in Information } \\
\text { Provision }\end{array}$} & Yes & $48(15.0 \%)$ & \\
\hline & No & $7(2.2 \%)$ & \\
\hline & N/A & $265(82.8 \%)$ & \\
\hline \multirow{9}{*}{$\begin{array}{l}\text { Reason Not } \\
\text { To Consider } \\
\text { Nursing }\end{array}$} & Social Recognition & $1(0.3 \%)$ & \\
\hline & Not Right for Them & $111(34.7 \%)$ & \\
\hline & Female Job & $6(1.9 \%)$ & \\
\hline & Stressful Job & $31(9.7 \%)$ & \\
\hline & Low Pay & $13(4.1 \%)$ & \\
\hline & School Record & $48(15.0)$ & \\
\hline & Lack of Information & $37(11.6 \%)$ & \\
\hline & Others & $18(5.6 \%)$ & \\
\hline & N/A & $55(17.2 \%)$ & \\
\hline \multirow{2}{*}{$\begin{array}{l}\text { Whether they } \\
\text { will participate } \\
\text { in information } \\
\text { provision or not }\end{array}$} & Yes & $77(24.1 \%)$ & \\
\hline & No & $187(58.4 \%)$ & \\
\hline
\end{tabular}

That is, in the nurse image perceived by high school students, the more the subjects to consult with for a nurse job when selecting a career and the more whether they have intention to consider nursing or not, the more nurse image is affected. Whether they have intention to consider nursing or not had a correlation with why they consider nursing and why they do not (Table 4).

\subsection{Relationship between Nurse Image by Sub-realms Perceived by High School Students and a Career Choice}

The occupational image had a correlation with business image $(\mathrm{r}=.642, \mathrm{p}=.000)$, the social image did with business image $(\mathrm{r}=.530, \mathrm{p}=.000)$ and the occupational image $(\mathrm{r}=.671, \mathrm{p}=.000)$, and individual image did with business image $(\mathrm{r}=.831, \mathrm{p}=.000)$, the occupational image $(\mathrm{r}=.609, \mathrm{p}=.000)$, and the social image $(\mathrm{r}=.581$, $\mathrm{p}=.000)$. The subjects to consult with for a career choice had a correlation with business image $(\mathrm{r}=-.132, \mathrm{p}=.018)$ and individual image $(\mathrm{r}=-.137, \mathrm{p}=.014)$, whether they have intention to consider nursing or not did with the occupational image $(\mathrm{r}=-.205, \mathrm{p}=.000)$ and the social image $(\mathrm{r}=-.237, \mathrm{p}=.000)$, why they consider nursing

Table 4. Relationship between nurse perceived by high school students and characteristics of career choice

\begin{tabular}{|c|c|c|c|c|c|}
\hline & \multicolumn{5}{|c|}{$\begin{array}{c}\text { Relationship Between Nurse Image Perceived By High School } \\
\text { Students and Characteristics of Career Choice }\end{array}$} \\
\hline variables & $\begin{array}{l}\text { Perceived } \\
\text { Nurse } \\
\text { Image }\end{array}$ & $\begin{array}{c}\text { Subjects of } \\
\text { Consultation }\end{array}$ & $\begin{array}{l}\text { Whether } \\
\text { they have } \\
\text { intention } \\
\text { to consider } \\
\text { nursing or } \\
\text { not }\end{array}$ & $\begin{array}{c}\text { Reason To } \\
\text { Consider } \\
\text { Nursing }\end{array}$ & $\begin{array}{l}\text { Reason } \\
\text { Not To } \\
\text { Consider } \\
\text { Nursing }\end{array}$ \\
\hline $\begin{array}{c}\text { Perceived } \\
\text { Nurse Image }\end{array}$ & 1 & & & & \\
\hline $\begin{array}{c}\text { Subjects of } \\
\text { Consultation }\end{array}$ & $\begin{array}{l}-.124^{*} \\
(.027)\end{array}$ & & & & \\
\hline $\begin{array}{l}\text { Whether } \\
\text { they have } \\
\text { intention } \\
\text { to consider } \\
\text { nursing or } \\
\text { not }\end{array}$ & $\begin{array}{l}-.133^{*} \\
(.017)\end{array}$ & $\begin{array}{l}.035 \\
(.530)\end{array}$ & & & \\
\hline $\begin{array}{c}\text { Reason to } \\
\text { consider } \\
\text { nursing }\end{array}$ & $\begin{array}{l}-.122^{*} \\
(.029)\end{array}$ & $\begin{array}{l}.047 \\
(.400)\end{array}$ & $\begin{array}{l}.969^{* *} \\
(.000)\end{array}$ & & \\
\hline $\begin{array}{c}\text { Reason Not } \\
\text { To Consider } \\
\text { Nursing }\end{array}$ & $\begin{array}{l}.114^{*} \\
(.041)\end{array}$ & $\begin{array}{l}.013 \\
(.823)\end{array}$ & $\begin{array}{c}-.666^{* *} \\
(.000)\end{array}$ & $\begin{array}{l}-.668^{* *} \\
(.000)\end{array}$ & 1 \\
\hline
\end{tabular}

* Significant Level <.05 ** Significant Level <.01 
did with the occupational image $(\mathrm{r}=-.195, \mathrm{p}=.000)$, the social image $(\mathrm{r}=-.221, \mathrm{p}=.000)$, and whether they have intention to consider nursing or not $(\mathrm{r}=.969, \mathrm{p}=.000)$, and why they do not consider it did with the occupational image $(\mathrm{r}=.143, \mathrm{p}=.010)$, the social image $(\mathrm{r}=.144$, $\mathrm{p}=.010)$, whether they have intention to consider nursing or not $(\mathrm{r}=-.666, \mathrm{p}=.000)$, and why they consider it $(\mathrm{r}=-.668, \mathrm{p}=.000)($ Table 5$)$.

\section{Discussion}

In this study, when the students had nursing practitioners around, the nurse image was good, which was similar to the studies of Park and Yang 9 , and Yang ${ }^{10}$, however, which was different from the results of studies of Lee \& $\mathrm{Kim}^{11}$ that there was no difference in the nurse image according to whether there were nurses among relatives or not. When they have a nurse around including relatives and if he or she becomes a good role model, it is thought that the positive nurse image is formed and he or she is likely to advise the students to decide for the department of nursing science. As it was indicated that the nurse image was formed a lot through a hospital visit and the experience of hospitalization, it could be known that a direct contact with a nurse is important. This is similar to the results of the study of Seo ${ }^{1}$, therefore, it is necessary that the nurses who work at a hospital need to be a good role model for caring a patient so that high school students may have a positive nurse image. Also, in keeping in mind that the actual role of a nurse is important in forming the nurse image $\mathrm{e}^{12}$, he or she needs to engage in nursing with a consistent, kind attitude even when he or she suffers from a heavy workload. Mass media like a TV may distort the image of professional nurses ${ }^{13}$, recently the supply of a computer has been spread and a young generation is receiving a lot of information through Internet, so it is considered that it is necessary to grasp the effect of mass media or internet use on the formation of the nurse image. There was no statistically significant difference in whether they have

Table 5. Relationship between nurse image by sub-regions perceived by high school students and characteristics of career choice

\begin{tabular}{|c|c|c|c|c|c|c|c|c|}
\hline & \multicolumn{8}{|c|}{$\begin{array}{l}\text { Relationship Between Nurse Image by Sub-regions Perceived by High School Students and } \\
\text { Characteristics of a Career Choice }\end{array}$} \\
\hline variables & $\begin{array}{l}\text { Business } \\
\text { Image }\end{array}$ & $\begin{array}{l}\text { Occupational } \\
\text { Image }\end{array}$ & $\begin{array}{l}\text { Social } \\
\text { Image }\end{array}$ & $\begin{array}{l}\text { Individual } \\
\text { Image }\end{array}$ & $\begin{array}{c}\text { Subject } \\
\text { sof Career } \\
\text { Consultation }\end{array}$ & $\begin{array}{l}\text { Whether } \\
\text { they have } \\
\text { intention } \\
\text { to } \\
\text { consider } \\
\text { nursing }\end{array}$ & $\begin{array}{l}\text { Reasonto } \\
\text { consider } \\
\text { Nursing }\end{array}$ & $\begin{array}{c}\text { Reason } \\
\text { Not To } \\
\text { Consider } \\
\text { Nursing }\end{array}$ \\
\hline Business Image & 1 & & & & & & & \\
\hline Occupational Image & $\begin{array}{l}.642^{* *} \\
(.000)\end{array}$ & 1 & & & & & & \\
\hline Social Image & $\begin{array}{l}.530^{* *} \\
(.000)\end{array}$ & $\begin{array}{l}.671^{* *} \\
(.000)\end{array}$ & 1 & & & & & \\
\hline Individual 1 Image & $\begin{array}{l}.831^{* *} \\
(.000)\end{array}$ & $\begin{array}{l}.609^{* *} \\
(.000)\end{array}$ & $\begin{array}{l}.581^{* *} \\
(.000)\end{array}$ & 1 & & & & \\
\hline $\begin{array}{c}\text { Subjects ofCareer } \\
\text { Consultation }\end{array}$ & $\begin{array}{l}-.132^{*} \\
(.018) \\
\end{array}$ & $\begin{array}{l}-.065 \\
(.246) \\
\end{array}$ & $\begin{array}{l}-.082 \\
(.145) \\
\end{array}$ & $\begin{array}{l}-.137^{*} \\
(.014)\end{array}$ & 1 & & & \\
\hline $\begin{array}{l}\text { Whether they have intention } \\
\text { to consider nursingor not }\end{array}$ & $\begin{array}{l}-.070 \\
(.212)\end{array}$ & $\begin{array}{l}-.205^{* *} \\
(.000)\end{array}$ & $\begin{array}{l}.237^{* *} \\
(.000)\end{array}$ & $\begin{array}{l}-.086 \\
(.124)\end{array}$ & $\begin{array}{l}.035 \\
(.530)\end{array}$ & 1 & & \\
\hline Reason To ConsiderNursing & $\begin{array}{l}-.061 \\
(.274) \\
\end{array}$ & $\begin{array}{l}-.195^{* *} \\
(.000)\end{array}$ & $\begin{array}{l}-.221^{* *} \\
(.000) \\
\end{array}$ & $\begin{array}{l}-.079 \\
(.157) \\
\end{array}$ & $\begin{array}{c}.047 \\
(.400) \\
\end{array}$ & $\begin{array}{l}.969^{* *} \\
(.000)\end{array}$ & 1 & \\
\hline $\begin{array}{c}\text { Reason } \\
\text { Not To Consider } \\
\text { Nursing }\end{array}$ & $\begin{array}{l}.075 \\
(.178)\end{array}$ & $\begin{array}{l}.143^{*} \\
(.010)\end{array}$ & $\begin{array}{l}.144^{*} \\
(.010)\end{array}$ & $\begin{array}{l}.100 \\
(.075)\end{array}$ & $\begin{array}{l}.013 \\
(.823)\end{array}$ & $\begin{array}{c}-.666^{* *} \\
(.000)\end{array}$ & $\begin{array}{c}-.668^{* *} \\
(.000)\end{array}$ & 1 \\
\hline
\end{tabular}

* Significant Level $<.05{ }^{* *}$ Significant Level $<.01$ 
the experience of information provision on nursing or not, which corresponds to the study results of Lee ${ }^{14}$ that there was no significant difference between the group which had the experience of information provision on nursing and that which had no experience of it in male high school students. In order to improve that, it is suggested that there should be a systematic support so that the wide opportunity of nursing is provided and developmental experience is done. A review of the subjects to consult with for a career revealed that 151 students (47.2\%) consulted with their parents, $81(25.3 \%)$ did with their friends or seniors, and 46(14.4\%) did with teachers. Contrary to the thought of the general public that a teacher may play a big role in the career choice of students as they spend mostly in a school, it was revealed that the subjects of career consultation were mainly parents, friends or seniors. This corresponds to the results of the studies of Lee ${ }^{14}, \mathrm{Lm}^{7}$, Jang ${ }^{16}$ that high school students mainly consult with their parents or friends for their careers. However, though a teacher is not mainly the subject to consult with, he or she may affect the career choice through classes, and considering the state that there is meeting between parents and a teacher when students select a department, it is considered that the role of a teacher affects both students and parents indirectly.

\section{Conclusion and Recommendations}

To lay the foundation of strategy development for improving the nurse image of the future by grasping the recognition and image of a nurse of high school students and to provide the basic data for promoting the application of excellent students to nursing by grasping the high school students who will select nursing and the awareness which can affect their careers, this study was conducted for the high school students who were in the stage of career choice in a medical, social environment which undergoes a sudden change. The study was conducted from June 20, 2014 to July 31, 2014 for the male and female students of 4 high schools in $\mathrm{M}$ and $\mathrm{S}$ regions. The tool used in this study was the tool of nurse image developed and used by Lee ${ }^{8}$. As a result of measuring reliability, it was Chronbach's $\alpha=.93$. Besides that, the tool of career choice used by Moon ${ }^{7}$ was used. The collected data was analyzed by frequency, percentage, $\mathrm{t}$-test, ANOVA, and Pearson's correlation coefficients according to the study purpose with SPSS Window 21.0 Program. 1) Review of the correlation between nurse image perceived by high school students and the characteristics of career choice revealed that the nurse image perceived by high school students had a correlation with the subjects to consult with for a career choice $(\mathrm{r}=-.124, \mathrm{p}=.027)$, whether they have intention to consider nursing or not $(\mathrm{r}$ $=-.133, \mathrm{p}=.017)$, why they consider nursing $(\mathrm{r}=-.122$, $\mathrm{p}=.029)$, and why they don't $(\mathrm{r}=114, \mathrm{p}=.041)$. That is, in the nurse image perceived by high school students, the more there are the subjects to consult with for a nurse job when choosing a career and the more that they have intention to consider nursing, the more the nurse image was affected. Whether they have intention to consider nursing or not had a correlation with why they consider nursing and why they do not. 2) As a result of examining the correlation between nurse image by the sub-regions perceived by high school students and the characteristics of a career, the occupational image had a correlation with business image $(r=.642, \mathrm{p}=.000)$, the social image did with business image $(r=.530, p=.000)$ and the occupational image $(\mathrm{r}=.671, \mathrm{p}=.000)$, individual image did with business image $(\mathrm{r}=.831, \mathrm{p}=.000)$, the occupational image $(\mathrm{r}=.609, \mathrm{p}=.000)$, and the social image $(\mathrm{r}=.581$, $\mathrm{p}=.000)$. The subjects to consult with for a career choice had a correlation with business image $(r=-.132, \mathrm{p}=.018)$ and individual image $(\mathrm{r}=-.137, \mathrm{p}=.014)$, whether they have intention to consider nursing or not did with the occupational image $(\mathrm{r}=-.205, \mathrm{p}=.000)$, and the social image $(\mathrm{r}=-.237, \mathrm{p}=.000)$, why they consider nursing did with the occupational image $(r=-.195, \mathrm{p}=.000)$, the social image $(\mathrm{r}=-.221, \mathrm{p}=.000)$, and whether they have intention to consider nursing $(r=.969, \mathrm{p}=.000)$, and why they do not consider nursing did with the occupational image $(\mathrm{r}=.143, \mathrm{p}=.010)$, the social image $(\mathrm{r}=.144, \mathrm{p}=$ .010 ), and whether they have intention to consider nursing $(\mathrm{r}=-.666, \mathrm{p}=.000)$. The results above indicated that the nurse image perceived by high school students was affected by whether in the nurse image perceived by high school students, the more there are the subjects to consult with for a nurse job when choosing a career and the more that they have intention to consider nursing, the more the nurse image was affected. Therefore, it is necessary to give an opportunity to provide information consistently. Also, it is hard to say that this study represents the population because it was conducted only for the high school students of a few regions and sampling method was convenience 
sampling. Therefore, it is suggested that the results of this study will be expanded to the whole high school students in Korea and be studied repeatedly.

\section{References}

1. Seo EH. Nurses' Image Perceived by Nursing and Health Allied College Students in Korea. Chonnam National University. Gwangju. 2005.

2. Kim HS, Park JH, Seo EY, Oh HM, Lee SM, Lee SS, Lee JU, Lee HJ. A study on nurse's image of university students. Journal of Ewha University of Nursing. 2001; 34:54-69.

3. Jeong HS, Yoo YS. Image of nurses as perceived by nursing students and image determinants. Journal of Korean Community Health Nursing Academic Society. 2010; 24(1):29-38.

4. Park SA. The portrayal of nurses in mass media: a content analysis of hospital administration journals. Seoul: Chung Ang University; 2008.

5. Kim HJ, Kim HO. A study on image of the nurse. Journal of Korean Nursing Administration Academic Society. 2001; 7(1):97-110.

6. Kim CHG. Career education and Career guidance. Seoul. Dongmunsa. 2005.

7. Moon YJ. A study on the perception of nursing, male nursing, male nurses, and nursing as possible career consideration-focused on male high school students, parents, and teachers. Kyungnam: Gyeongsang National University; 2010.

8. Lee DS. A study on the nurses' image perceived by laywoman and man. Seoul: Hanyang University; 1995.

9. Park MH, Yang JJ. A study on the nurse's image perceived by nursing college students. Journal of Korean Academy of Nursing Administration. 2002; 8(1):107-21.

10. Yang JJ. Nurses' image perceived by student nurses before and after their first clinical practice. Journal of Korean Academy of Nursing Education. 2003; 9(1):64-72.

11. Lee SH, Kim JA. Image of nurse and it's determinants among nursing students and non-nursing students. Journal of Korean Nursing Administration Academic Society. 2006; 12(1):52-62.

12. Park MY. Survey on Nurse's Image. Daejeon: Chunhnam National University; 2001.

13. Olshansky E. Why not become an M. D.? A perspective from a student nurse on the profession's image. Journal of Professional Nursing. 2009; 25(2):65-6.

14. Lee JH. A study on nursing recognition of male high school students. Seoul: Yonsei University; 1996.

15. Lm BU. A study on the improvement of academic career education high school. Daejeon: Daejeon University; 2005.

16. Jang YS. A study on the factors of career choice that high school students perceive. Daejeon: Hannam University; 2003. 